\title{
POLICY DILEMMAS IN URBAN EDUCATION: Addressing the Needs of Poor, At-risk Children
}

\author{
JEFFREY A. RAFFEL * \\ University of Delaware \\ WILLIAM LOWE BOYD \\ Pennsylvania State University, University Park \\ VERNON M. BRIGGS, JR. \\ Cornell University \\ EUGENEE. EUBANKS \\ University of Missouri, Kansas City \\ ROBERTO FERNANDEZ \\ Northwestern University
}

\begin{abstract}
The changing demographic face of the nation's cities has placed tremendous burdens on urban schools. No consensus on solving the problems of urban education exists. Successful policy alternatives should be: (I) comprehensive (i.e., deal with urban problems beyond education, such as health status and poverty), (2) supported by adequate resources, (3) universal and targeted (i.e., focused on children), (4) value-based (i.e., promoting the value of education), (5) communitybased, and (6) research-based. Policy alternatives that will improve urban education include those that (l) reaffirm programs that work (i.e., Head Start), (2) reallocate resources to students in need (e.g., state equalization), (3) restructure the school workplace (e.g., choice/market alternatives and school restructuring), and (4) relink the schools to society (e.g., accelerated schools). Where the nation will get the political and economic will to improve urban schools and the condition of children in the United States is not now apparent.
\end{abstract}




\section{STATUS OF EDUCATION IN URBAN AREAS}

The current status of education in urban areas as we can now measure is quite poor and there are many reasons for pessimism as for optimism about the future. While we have much anecdotal and school district evidence about urban education and evidence about student achievement linked to demographic characteristics, we do not have systematic information necessary to define the urban dimensions of the problem. Those organizations which report national data generally do not report it by urban place and those that report urban data do not generally include educational output data. For example, although the National School Boards Association's (1988) urban school districts report has many statistics about the nature of these districts, it reports no achievement outputs.

Dropout rates exceed $50 \%$ in many cities, many of whose students completing high school lack adequate reading and writing skills and urban schools are producing few graduates capable of functioning in an economic system increasingly technologically and service based. Concern about economic productivity in the international arena and the erosion of individual life chances in an increasingly technological society have increased the importance of national educational issues. Extending the analogy from A Nation at Risk (U.S. National Commission on Excellence in Education, 1984), "if an unfriendly foreign power had attempted to impose on America the mediocre educational performance that exists today, we might well have viewed it as an act of war," our urban schools continue to be the major battlefield of this invasion. One could argue that America's urban educational casualties are high, the war is being lost, the future looks bleaker, we are not properly organized to achieve victory, and we are losing this war in large part because we never made a commitment of resources (as opposed to rhetoric) to win.

We argue that the changing demographic face of the nation's cities has placed tremendous burdens on our urban schools. Many children come to urban schools not prepared to learn; many are negatively affected by poverty, drugs, alcohol, poor health; many have physical and mental disabilities derived from these causes. To the extent that schools reflect society, our urban schools now face problems that are quantitatively and qualitatively more difficult than those experienced in previous decades. While many view schools and education as the keys to solving the problems of drugs, crime, poverty, and the myriad of urban ills, the opposite is more the reality: The success of urban schools is dependent upon our nation's health, criminal justice, economic, and other systems. Too many leave the nation's problems on the doorstep of the urban school. While we review policy alternatives that will improve urban education by reaffirming programs that work, reallocating resources to students in need, restructuring the school workplace, and relinking schools to society, these alternatives rest upon the base of the improved status of children in our society.

\section{Demographics}

America's students increasingly have the characteristics of the educationally disadvantaged (i.e., they are increasingly minority and poor) and it is the cities where disadvantaged students are (and will be) concentrated. After defining the educationally disadvantaged as those students who "have been exposed to inappropriate educational 
experiences in at least one of ... three educational domains"-formal schooling, family, and community-Pallas, Natriello, and McDill (1989) conclude that "even conservative estimates put the proportion of educationally disadvantaged students at one third." This proportion is likely to increase as the population of those 0 to 17 years old increases by $17 \%$ through 2020 . The proportion of children in poverty in the United States is expected to increase from about $16 \%$ in $1979,22 \%$ in 1983, to $27 \%$ in 2020 (Pallas, Natriello, \& McDill, 1989). A Phi Delta Kappan special report (Reed, Craig, \& Sautter, 1990 ) concluded that "the nation's children are worse off than ever." Not surprisingly, other indicators of educational disadvantage status are expected to increase (most strikingly the number of children living with mothers who have not completed high school) from 13.6 million in 1983 to 21.2 million in 2020 .

Overall, Pallas et al. (1989, pp. 18-19) expect "a remarkable transformation of the American youth population. Whereas almost three of every four children in 1982 were white, only about one of two children in 2020 will be white... The number of white non-Hispanic youngsters is expected to decline about $13 \%$ from 1982 to 2020 [while] the number of Hispanic children will more than triple over this period, increasing from 5.9 million in 1982 to 18.6 million in 2020 ." The number of black youth is also expected to increase by 2.6 million during this period.

These educationally disadvantaged youth are disproportionately concentrated in our urban school districts, especially in our largest school districts, and this has led Clark and Astuto (1990, p. 19) to conclude that "The condition of poverty for urban children is out of control." The Council of the Great City Schools (1986) collects data on its member districts, 45 of the largest urban public school systems in the nation. Its districts educate $11 \%$ of the nation's public school students, but its 1984 enrollments indicate that its schools educate $28.7 \%$ of all racial minority children in the nation: $32.3 \%$ of blacks, $26.8 \%$ of Hispanics, and $20.1 \%$ of Asians.

Much of the change in urban youth demographics is due to mass immigration, one of the least discussed yet most important forces impinging on urban education in many communities. We will focus on its nature and impact below.

\section{Role of Immigration}

From World War I through to the mid-1960s, immigration steadily declined in importance. The foreign born population had fallen from $13.2 \%$ of the population in 1920 to $4.7 \%$ in 1970, but by 1980 , the downward trend had been reversed. The foreign born population had grown to $6.2 \%$ (a $46 \%$ increase) over the preceding decade. Given the expansive immigration policies of the 1980s, the Census data for 1990 are expected to show that about $9 \%$ of the population (or one of every 11 persons in the country) is foreign born. Furthermore, all of the "official" figures are suspect of being far too low due to the alleged undercounts associated with illegal immigration. The influx of immigrants has been so substantial that a recent study proclaimed that "America's biggest import is people" (Oxford Analytica, 1986, p. 20). In 1990 Congress passed a new immigration bill increasing the number of legal immigrants by $35 \%$, to 700,000 annually.

The reawakening of the sleeping giant of immigration from the nation's past can be attributed directly to the passage of the Immigration Act of 1965. That legislation sought to purge the overt racism associated with the "national origins" admission system that 
had prevailed since 1924 (Briggs, 1984). No one, however, anticipated that the ensuing product would rekindle the mass immigration experience. About 1.3 million foreign born them are a substantial number of children. Many more can be expected as the result of the new immigration legislation that went into effect in fiscal year 1992.

The current wave of "immigration is overwhelmingly an urban phenomenon"(Bogen, 1987 , p. 60). In 1980, 92\% of the foreign born population that was counted by the Census resided in metropolitan areas, compared to $72 \%$ of the native born population. The 1990 Census can be expected to show an even wider gap. Moreover, many of the nation's largest cities (e.g., New York, Los Angeles, Chicago, Houston, Miami, Denver, and
San Antonio) are bearing the brunt of immigrant accommodation pressures.

The flow of immigrants is more than sheer numbers. It is also characterized by unprecedented racial and ethnic diversity. A disproportionate number of the immigrants are coming from the less economically developed nations of the world (especially those who have immigrated illegally and those who have entered as refugees). As a consequence, many are poor, unskilled, do not speak English, and are illiterate in their native language. The challenge to reach such a diverse student body adds significantly to the administrative
and financial burdens that already beset many urban school systems.

Mass immigration has helped to increase the percentage of at-risk children served by urban schools. Ornstein reported that in 1950 approximately one in ten students in school in the 14 largest cities were considered disadvantaged. In 1960 this proportion was one in three. In 1970 it was one in two. The Council of Great City Schools (1987) estimated that $80 \%$ of the students in its schools were eligible for a free or reduced price lunch. The concentration of poverty and minorities in US central cities has led to a vision of our cities as urban reservations (Waste, 1989).

\section{Student Performance and Outcomes}

The demographic situation described above is associated with bleak descriptions of the educational results in many inner city schools. Wilson (1987, pp. 57-58) has reported:

of the 39,500 students who enrolled in the ninth grade of Chicago's public schools in 1980 , and who would have normally graduated from high school four years later in the spring of 1984 , only 18,500 (or $47 \%$ ) graduated; of these only 6,000 were
capable of reading at or above the national twelfth-grade level.

The situation is even bleaker for those minority students who attended segregated inner city high schools, two-thirds of whom did not graduate. "Of the 9,500 who did graduate, average" (quoted in Wilson, 1987).

While we lack a common definition and quantitative report by school district, the dropout rate of urban students is reported anecdotally to be quite high. In some central cities, rates of minority dropout exceed $60 \%$. The National Center for Educational Statistics (1990) reported that although the black dropout rate declined from 1980 to 1987, the Hispanic dropout rate has remained near $10 \%$ annually throughout this period.
The report does not list dropouts by urban place. 
The high dropout rate in some cases may be a result of the violence surrounding and sometimes entering the urban school. Boyd $(1990$, p. 16) notes that "One of the most disturbing changes affecting urban school systems is the escalation of violent crime and teenage gang activity, often associated with the exploding problem of illegal drugs." According to Boyd, "sheer survival [is] a paramount concern in some inner city neighborhoods; just getting to and from school can be a very grave concern."

The rate of urban students going on to college and productive careers is low. From 1977 to the mid-80s there was a "marked decline in college entry among black high school graduates" (Jaynes \& Williams, 1989, p. 338). Recently, the rate has returned to the previous level of $30 \%$. The William T. Grant Foundation Commission on Work, Family, and Citizenship (1988, p. 282) concluded that those who do not go to college are the "forgotten half," with greatly dimmed economic prospects, many "trapped in an economic limbo of unemployment, part-time jobs, and poverty level wages."

There is little doubt that in our cities there is a confluence of poor minority children with educational problems and that the number of students with problems will increase rather than decrease in the decade ahead.

\section{Resources}

Despite the obvious needs of urban students and the potential return on investment from fulfilling these needs, the resources to meet these challenges have not been committed and seem unlikely to be committed in the future.

Total and current expenditures per pupil, in constant dollars, after a lull from 1978 through 1982 are again on the increase to $\$ 5,172$ and $\$ 4,719$, respectively, in 1989 (National Center for Educational Statistics, 1990). It is not clear that urban schools are fully sharing in this increase. In this decade federal funding, which helps to offset local and state inequities, has not been maintained for education in general or for urban education in particular (National Education Association, 1990; Verstegen \& Clark, 1988). Clark and Astuto (1990, p. 11) report that since 1981 outlays for the budget of the Department of Education have dropped from $0.6 \%$ to $0.45 \%$ of the GNP, decreased from $2.5 \%$ to $1.8 \%$ of the federal budget, and reduced the federal share of expenditures for elementary and secondary education from $8.7 \%$ to $6.2 \%$. The National Educational Association (NEA) has pointed out that "if education spending had remained constant at 2.5\% of the federal budget-its share in FY 1980-America's education institutions would have some $\$ 6.7$ billion more to spend for essential education programs in FY 91" (NEA, 1990).

Despite major challenges to state funding laws, school finances remain inequitable, or at least inadequate, across many city and suburban lines. (See the chapters on economic development and public finance in this volume for excellent discussions of intrametropolitan financial disparities and the worsening financial condition of cities.) "Political support for public education in the cities is losing its middle class base, as those parents not only decline in number but more frequently opt for non-public education" (National School Boards Association, 1988, p. 15). However, recent court decisions in Kentucky and Texas offer some hope that some poor schools may get the targeted financial assistance that they need. The most positive decision is the New Jersey decision where the state's highest court decided that urban school students 
should receive what the wealthier school districts in the state were receiving (Abbott
v. Burke, 1990).

The financial needs of urban schools go beyond the need to meet the immediate educational needs of their clientele. While most know that urban school districts find it far harder than other school districts to locate quality teachers, especially from minority backgrounds (Council of Great City Schools, 1988), few recognize the immense need for school repair and construction in our cities. Urban school buildings are part of the nation's infrastructure in need of repair and replacement and, perhaps, expansion. The school buildings in our major cities are in a state of disrepair that will cost billions (Piccigallo, 1989). The Council of Great City Schools (1987) puts a \$5 billion price tag on the need in its districts.

\section{Implications}

In its basic conclusion the Kerner Commission (National Advisory Commission on Civil Disorders [NACCD], 1968) has proven prophetic. Years have reinforced the development of a dual society (although not quite in the manner predicted by the Commission), one white and rich and one black and poor. There is an increased concentration of educational problems in our larger central cities and "the schools have failed to provide the educational experience which could overcome the effects of discrimination and deprivation" (NACCD, 1968, pp. 424-425), but the role of immigrants, Hispanics, and other nonblack minorities will play a larger role than predicted. What policy alternatives could improve urban education? Below we address this question, focusing on elementary and secondary school-aged children across the nation's cities and metropolitan areas where we are concerned not only with the extreme, the truly disadvantaged in our largest cities, but also with those children at-risk of never making it into the national mainstream in smaller cities and struggling suburban areas.

We must begin with the central finding of research on student achievement: Student background is highly related to student achievement. Thus, given an increase in the number and percentage of at-risk students projected across this nation and especially in our cities, problems of urban education are likely to get much worse before they
get better.

Alternatives to improve urban education must be evaluated with this relation in mind. William Boyd (1990) points out that most educational reform alternatives have focused on within-school factors, those most under the control of education officials. However, the linkage of school success to external factors, including the factors identified with at-risk students above (the family and the community) suggests that we look closely at broader reforms as well.

The strategies examined below revolve around: reaffirming the current structure of schools while responding better to the needs of students, reallocating resources (students and finances), restructuring the school workplace or the basic authority system of public schools, and relinking schools to society.

As we examine these alternatives, we not only evaluate their effectiveness and feasibility but also attempt to establish criteria for judging policy responses to the problems of urban education. 


\section{POLICY ALTERNATIVES}

\section{Reaffirmation}

A number of alternatives reaffirm the basic structure of US schools while seeking to improve them. These alternatives include those that seek to compensate for experiences which educationally disadvantaged children may lack, improve instruction and school management, and respond more appropriately to new clients.

\section{Compensatory and Preschool Education}

A variety of programs has been developed to teach disadvantaged children the skills, concepts, and attitudes which conventional schools expect, but which the children frequently lack because they have been trained and socialized in ways that are in opposition to the school structure and learning process. Preschool programs such as Head Start try to prepare children for the demands of schools. There have been many evaluations of Head Start programs, most of which have concluded that, although the programs vary from place to place, they generally are valuable. The potential for longterm benefits from preschool programs, at least exemplary ones, has been documented rather dramatically in Schweinhart and Weikart's (1980) longitudinal study of participants in the Perry Preschool Project. Schorr (1988) claims that Head Start has produced gains of over $\$ 4$ for every $\$ 1$ invested. Advocates of Head Start decry national underinvestment and that only about $20 \%$ of the eligible children have been served. Legislation passed in 1990, if fully funded, will increase coverage to nearly $100 \%$.

Compensatory education programs, such as the federally funded Chapter 1 (formerly Title 1) program, provide remedial instruction to help disadvantaged students who are below grade level catch up. Like Head Start, Chapter 1 has been an extremely successful program if one judges it in terms of the political support it garnered. As with Head Start, the number of eligible children not served by Chapter 1 has been a very sore point. Kirst and Gifford (1988, p. 8 ) note that:

From its inception the Title 1 program has not adequately targeted funds on the children from poverty families with the greatest educational needs. Despite the stated goal of reaching low scoring students in high poverty schools, hundreds of inner city middle and secondary schools that average in the bottom quartile of achievement and that graduate under $60 \%$ of their students do not have a Chapter 1 program because of insufficient funds. At the same time, in suburban systems throughout the nation, schools with fewer than $10 \%$ of the student body living in poverty receive Chapter 1 funds. In fact, as structured today, Chapter 1 programs do not serve $68.6 \%$ of the nation's poor students, $64.9 \%$ of American students achieving below the 25th percentile in achievement, $57.9 \%$ of poor and low achieving students, and even $55.1 \%$ of poor and low achieving students who are enrolled in Chapter 1 schools [emphasis in original].

Again, like Head Start, there have been innumerable studies and evaluations of Chapter 1 programs. One of the main controversies has been over the merits of Chapter 1 "pull-out" programs, which take children out of regular classrooms for a portion of the day to receive remedial instruction. Increasingly, there is agreement that pull-out 
programs are poorly integrated with regular instruction, that they tend to disrupt regular instruction, and also that they label students (Johnston, Allington, \& Afflerbach, 1985). Still, the Compensatory Education Study, mandated by Congress in 1974, found that "Title 1 services were delivered to appropriate children and that the program, when stable and well implemented, enhanced student achievement [emphasis in original]" (Leviton \& Boruch, 1984, pp. 300-301). However, Kennedy, Birman, and Demaline (1986, p. viii) conclude that "Students who discontinue Title 1 appear gradually to lose the gains they made when receiving services. Chapter 1 students with very low achievement scores appear to maintain their relative academic positions but not to move ahead." A further problem, these researchers found, is that "the achievement gap between disadvantaged and advantaged students appears to widen during the summer months" (Kennedy, Birman, \& Demaline, 1986, p. viii).

Overall, however, although Head Start and Chapter 1 and various summer programs have been generally beneficial, they do not seem to make a large difference for most disadvantaged children. Extending coverage will help but not solve the educational problems of urban students.

\section{Bilingual Education}

For most immigrant groups, preservation of language and culture are often issues of paramount importance. Contrary to the predictions of melting pot theorists, the literature on the revival of ethnic heritage has argued that the preservation of language, culture, and ethnic ties has not diminished. For Hispanic groups, a key focus of this debate has been bilingual education. This term refers to all programs that potentially affect the language use or ability of non-English speakers.

Most bilingual education programs in the United States have as their goal the teaching of English to non-English speakers (Llanes, 1981). This goal followed from the major federal legislation that established bilingual education. All bilingual education programs assume that without command of English, children will be unable to complete schooling and succeed in American society. However, there is some debate on whether this must be done at the expense of proficiency in the mother tongue. Most bilingual education programs are transitional. The major issue is how best to transform the non-English speaker into an English speaker without having the person fall behind in school, get frustrated, and/or drop out of school.

The debate on bilingual education has two components: first, whether the goal of transitional bilingual education is valid, and second, how best to achieve the transition to English with the least harm to the child. The various bilingual programs that have been used reflect one side or the other of this debate. When no program at all exists, the term immersion is often used. Students are placed in classrooms where English is spoken and are given no or very little language help. There are four models of bilingual education programs: structured immersion, English as a second language, transitional bilingual education, and bilingual-bicultural education. The first three clearly have a transitional focus, while the last has as its goal the maintenance of the mother tongue and culture while learning English (Llanes, 1981).

While evaluating bilingual programs is difficult, a general conclusion is that some form of program, whether it be transitional bilingual education, structured immersion, or English as a second language, seems to aid the English and math scores of nonnative 
speakers of English (Baker \& de Kantor, 1981). It is difficult to evaluate the various bilingual programs because they have different goals and different outcomes. Evaluation is also hampered by lack of standardization of measured outcomes and of appropriate experimental controls. In spite of these shortcomings, it is possible to make some generalizations about the effectiveness of various bilingual education programs. The evidence concerning which strategy of teaching the majority language works best is more confused, but the bulk of evidence suggests that it depends on the program and the situation of the minority language. Much evidence suggests students do better when they are introduced to schooling in their native tongue first and then eased into English instruction (Carssud \& Curtis, 1980; McConnell, 1980). Well designed and well executed programs make a difference in the English and math proficiency of students while poorly conceived and poorly executed programs do not.

A crucial political issue for urban schools, however, is whether all immigrant groups, not just Hispanics, should be (and can be) offered adequate bilingual programs. When we acknowledge that the Great Cities Schools face a clientele speaking over 100 languages, the practical and financial problems to provide bilingual education can be overwhelming (Council of Great City Schools, 1987). While immigrant groups understandably see bilingual problems not only as educationally necessary but also as symbolically important, urban school districts will have to focus their bilingual efforts.

\section{Instructional Methods and Research and Capacity Building}

In the last decade much attention has been devoted to what leads to effective schools and improved learning within schools. Herbert Walberg (1984) has brought together much research on what schools can do to help children achieve more under the rubric of educational productivity. Henry Levin (1986) attached costs to alternatives to allow cost-effectiveness and comparisons of alternatives such as lower class size, computerbased instruction, and peer tutoring. Knapp and Shields (1990) summarized insights about what we know about instructing disadvantaged students. Ron Edmonds (1979a, $1979 \mathrm{~b}$ ) initiated the influential and ongoing "effective schools" movement, identifying the distinguishing features of schools where the students are achieving more than their social background would predict. Levine and Lezotte (1990) have identified and described "unusually effective schools." Eubanks (1990) has argued that urban schools need to develop organizational learning cultures within a new schema of learning.

Not all agree, however, that we have really progressed that far in understanding what we need to know about urban education and some have called for a much larger commitment to research. Wise (1990) suggests the need for the creation of a National Institute on Improving the Education of the Disadvantaged in Urban Schools funded at $\$ 50$ million per year. Is such an expenditure unrealistic? Perelman $(1990, p .13)$ reports that the Gillette Company spent about $\$ 200$ million in R\&D investment to create its new high tech razor blade over a 13 year period. Gillette "thus spent more to invent a better shave than all the states combined spent during the same period to develop a better technology for teaching and learning." We support the national institute idea, but even if we attempted to expand the most successful and best-researched reaffirmation policies, many urban school districts would not have the resources and willingness to adopt them. 


\section{Reallocation}

The second set of alternatives calls for reallocating resources to urban education and minority children. School desegregation advocates seek to ensure that minority children are educated with more affluent, powerful, and motivated majority students. Those seeking reallocation of financial resources hope to offset the added cost of educating at-risk students.

\section{School Desegregation}

Despite evidence that minority students achieve more in a desegregated setting, the climate for school desegregation is not a hospitable one. There is abundant evidence that school desegregation improves the achievement of minority students without affecting the achievement of whites. There is less consensus about why school desegregation has this impact. Among the explanations is that white students, who are often middle class, help set the school atmosphere and standards and that, when white students are served with minority students, appropriate resources are provided. For a good review of the consequences of school desegregation, see Rossell and Hawley (1983).

The public's opposition to forced busing, the increasingly conservative position of the courts on this issue, and the decreasing number of whites in central cities who could or would be involved in desegregation plans limits the utility of this alternative, whatever its merits. A recent review of the status of school desegregation (Bates, 1990) concludes that "at best our public schools are not progressing and at worst they are showing signs of resegregation...But for the most part, safe in their suburban enclaves, whites and middle class blacks can ignore the problems of urban schools." Taeuber (1990) concludes that few school districts have resegregated during the 1980 s, but his analysis admittedly is not sensitive to declines in white enrollment in city schools.

Orfield (Fiske, 1988) has shown that the goal of desegregation of urban schools for black students has been greatly retarded by the rapid growth in the number of Hispanic and Asian American students. As a consequence, urban black students have sustained "a severe increase in racial isolation" from the non-Hispanic white population. He also finds that the same can be said for many of the new immigrants who find themselves isolated and clustered together in ethnic enclaves.

Given the obstacles to compulsory school desegregation, it is encouraging to note that recent research indicates that voluntary desegregation built on magnet schools may be more effective than compulsory plans in increasing interracial exposure. Rossell's (1990) careful analysis of whether the "carrot or the stick" approach is more effective in increasing black-white interracial exposure in city and metropolitan school districts indicates that by the third or fourth year magnet plans produce more interracial exposure than mandatory plans. However, Rossell (1990, p. 109) concludes that "voluntary plans do not reverse the decline in interracial exposure resulting from the decline in the white birth rate. Mandatory plans do not appear to do so either."

\section{Financial Redistribution}

The New Jersey, Kentucky, and Texas school finance decisions have shown that school finance reform was not killed by the Rodriguez (San Antonio Independent 
School District v. Rodriguez, 1973) decision but lives within state constitutions and state courts. While such decisions will bring more resources to urban schools, it is unclear how many states will ultimately have to reallocate funds because of court decisions. La Morte (1989), in his analysis of state courts and the wealth disparity issue, notes that ten state supreme courts have upheld state school finance provisions while seven have held them unconstitutional. Findings that state finance systems are unconstitutional, however, may help rural even more than urban school districts, especially since municipal overburden has generally not been accepted as an argument for increased funding for urban school districts. The political obstacles to such financial reallocation, as the backlash to Governor Jim Florio of New Jersey indicates, remain great. Politics and reallocation, whether in the form of school desegregation or financial reallocation, do not mix well.

It is also clear that increased expenditures on schooling will not necessarily lead to increased academic achievement (Hanushek, 1986). For example, reductions in class size, at least within the ranges traditionally found in US schools, do not bring added achievement. Increased revenues for urban schools are necessary but not sufficient for educational improvement. Thus, many analysts have turned their attention away from resources and toward restructuring.

\section{Restructuring}

Significantly, sophisticated policymakers, analysts, and business leaders increasingly believe that real reform cannot be achieved without major changes in the way schools are structured and operate. Increasingly, academics, business leaders, and reformers agree that schools, as they are presently organized, are strongly inclined toward inefficiency and goal displacement. Critics and reformers break down into two camps regarding the source of this difficulty: Some stress dysfunctional organizational arrangements in the workplace while others claim the problem goes deeper, that fundamental features of the governance and incentive structures of public schools are dysfunctional. The workplace critics believe that organizational restructuring and new management practices could solve our problems (Carnegie Task Force on Teaching as a Profession, 1986; Sykes \& Elmore, 1989). In this they disagree with the incentive critics who contend that only fundamental changes in the authority, control, and incentive structures of public schools could succeed (Chubb \& Moe, 1988; Michaelsen, 1977 , 1981). Both camps agree that public schools presently have serious efficiency problems, but they part company about what has to be done to correct them.

\section{Changing the School Workplace}

The workplace critics claim that the pervasive disengagement of both teachers and students from teaching and learning in typical schools is, in large part, the product of an ill-designed workplace within an organizational structure that frustrates students, teachers, and school administrators (Meier, 1989). Typically, this structure isolates teachers, discourages teamwork and professionalism, provides inadequate rewards for teaching and learning, and makes unattainable demands on school administrators (Rosenholtz, 1985; Sykes \& Elmore, 1989). 
Schools presently, say Sykes and Elmore (1989), are really unmanageable; school administration, they contend, is virtually "impossible work" in the current structure of roles and relationships. Thus, workplace critics have led the movement to restructure schools. Theodore Sizer, Dean, College of Education at Brown University, has established the Coalition of Essential Schools, aimed at restructuring schools around a set of principles including "student as worker; teacher as coach." Dade County/Miami has restructured by moving toward school site management. Chicago has cut its central bureaucracy and established councils of parents, teachers, and community representatives at each school who can hire and fire the school's principal under the Chicago School Reform Act of 1988. Rochester is moving to school site management and performance-based teacher salaries. Five states over the past five years have developed incentive schemes to provide financial awards for high-performing schools. Moreover, even the top teacher union leader in the country, Albert Shanker (1990), has proposed a competitive financial incentive plan for schools, an idea unthinkable under the traditional equity norms of unions. While it is too early to determine how effective such restructuring will be in improving student achievement, it is clear that careful evaluation of restructuring initiatives is a necessary component of any urban education improvement strategy.

\section{Choice and Market Alternatives}

Rational choice theory begins with the assumption that individuals seek to maximize their welfare and, accordingly, make rational choices or decisions toward this end. In assessing the costs and benefits of alternative courses of action, they are sensitive to the incentive or reward structures in which they find themselves. Since public nonprofit organizations lack a profit motive, this leads to questions about the nature of the incentives that operate in its absence. For instance, given the tenuous nature of principals' authority in public schools and their dependence on the good will of teachers, why should principals risk trying to change things and increase educational productivity?

Analysts using the perspective of market-oriented political economy contend that the nonprofit, government-supported character of public human service organizations tends to create a perverse structure of incentives for employees (Michaelsen, 1977, 1981). In the quasi-monopolistic, consumer-insensitive setting of such organizations, the reward structure often is not oriented toward performance. In such a system the personal goals of employees in public schools often take precedence over the official goals of the schools because the costs of inefficient behavior, in terms of the official goals (such as student outcomes or consumer satisfaction), are low.

From the point of view of productivity, Chubb and Moe's $(1988,1990)$ analysis comparing the attitudes of public and private school teachers and administrators suggests that the political preoccupations set in motion by public education's governance structure have pervasive negative consequences for school effectiveness. Their Administrator and Teacher Survey was sent to about 500 schools included in the original "High School and Beyond" data set. They found that "private schools are more likely to possess the characteristics widely believed to produce effectiveness" and that these "differences across the sectors are anchored in the logic of politics and markets," one based on "a hierarchic system of democratic politics," and the other "controlled' by 
the market" (1988, p. 1065). Private schools are more likely to "have simpler, less constraining environments of administrators, school boards, and parents, [to be] more autonomous and strongly led,... have clearer goals and stricter requirements, and...put greater stress on academic excellence."

Chubb and Moe's analysis provides support for various kinds of parental choice plans and magnet school schemes that would leaven the public school environment with elements of the market dynamic. These options are controversial, to say the least, among both the public school lobby and those advocates of at-risk children who believe such plans tend to work against their interests. However, it appears possible to design plans that guard against the obvious pitfalls and foster not only parental and student choice among public schools, but also provide a range of schools of shared values and strong community that reflect the professional values and preferences of educators. To what extent such plans would increase academic success, however, is to be proven.

\section{Relinking Schools to Society}

Two alternatives propose to alter the linkage of schools to society. The cultural/social capital school asserts that the relation of schools to their communities must change. Alternatively, others are now focusing on the school to work transition.

\section{School to Work Transition}

The need for a literate society, capable of understanding societal issues, and for an informed electorate, capable of participating in government, were among the original justifications for the creation of our nation's public school system. As the economy of the United States has grown more complex, the role that education can play as a contributing force to the job preparedness of students has also become more prominent. Indeed, as the goods-production orientation has given way to the rise of the serviceoriented economy since the end of World War II, the importance of educational preparation for employment has become fundamental.

Entering the 1990s, $76 \%$ of the nonagricultural labor force of the United States is employed in the service sector. The U.S. Department of Labor (Personick, 1987) projects that $90 \%$ of the new jobs to be created in the decade of the 1990 s will be in service industries. The most rapidly growing sectors of the service industries are those associated with business services, educational services, legal services, and health services. The key feature of service employment is the stress placed on the development and possession of cognitive skills. It is the communicative arts (the ability to read, to write, to understand, to speak, and to relate to people, be they customers, supervisors, or fellow workers) that is the key to employment success. These are skills that disproportionately fall on the nation's educational system to provide. Manual jobs that rely largely on innate physical abilities are rapidly declining in terms of their necessity and their availability. In sharp contrast to the past, the job market can "no longer accommodate" those young people who do not complete and master the educational experience (U.S. Congress, 1988, p. 18). Educational standards that did not require mastery of these cognitive skills may have been acceptable in the past but they are "utterly irrelevant" to the needs of the present (U.S. Congress, 1988, p. 14). 
The evidence strongly suggests that many students, both among the college and noncollege bound, are deficient in these abilities. Accordingly, many students are not prepared for the new realities of the workplace.

If urban youth are to be given a fair chance to compete in the emerging postindustrial labor market, the school retention rates as well as the educational performances and expectations of these youth must be bolstered. A variety of responses have been suggested. Most students, as John Bishop (1989) noted, recognize that there are benefits to staying in school but too many students see few benefits from working hard in school. The incentives to study are weakest for those not planning to go to college. Tó often, according to Bishop, they are seeking only the credential, not the education. To overcome this phenomenon, Bishop suggests that employers give more weight when hiring and paying to those students who have taken more demanding courses. Bishop argues that such employment policies should be communicated by employers to schools, parents, and students. High school graduates should not automatically be relegated only to certain low wage jobs but, rather, they ought to be able to compete for jobs on the basis of the actual skills and the knowledge they have gained (Bishop, 1989).

Bishop also ${ }_{3}$ states that schools should require more homework and that students should devote far more time to completing assignments. Far less time should be spent on watching television and nonacademic diversions, such as part-time jobs after school and participation in extended athletic and extracurricular activities. Parental support, as well as policies to reduce the need for students in economic distress to work, will be essential to the accomplishment of these behavioral practices.

Attention also must be given to the provision of quality educational alternatives that are not entirely associated with future academic pursuits. In particular, this means more extensive opportunities for vocational and occupational preparations must be available for those students who do not intend to pursue higher education. The nation's apprenticeship training system also needs to be reoriented to be more accessible to youths as in many other industrialized nations (Hamilton, 1987). Some experimentation with the European apprenticeship model is now occurring and may lead to more widespread changes.

Successful school-employment linkages also depend on the enhanced involvement by employers and parents and students themselves in the design of the appropriate educational experience that balances academic preparation with emerging employment imperatives. In partial recognition of this need, businesses are increasingly becoming involved directly with schools in business partnerships. McGuire (1990) estimates that between 30,000 and 45,000 such partnerships may now exist, but we know little about what they do best and whether they have led to meaningful change.

While there are many potentially constructive proposals deriving from those concerned about the school to work transition, Berryman (1987) has argued that we do not yet adequately understand what leads to successful linkages. One unresolved problem, for example, is the extent to which schools which stress individualized success are counterproductive in a business environment moving toward increased emphasis on teamwork. In addition, we face the policy issue of deciding what part of work preparedness belongs in our schools $\mathrm{v}$. in our businesses. 


\section{Cultural/Social Capital}

Ogbu (1988) argues that the barriers to school success for black children in the US are much steeper than either the institutional deficiency theorists, who seek structural reform, or the developmental deficiency theorists, who stress compensatory programs, recognize.

He sees a cultural gap in his cultural discontinuities theory, distinguishing between the background and adaptive behaviors of immigrant minorities and castelike or involuntary minorities (Ogbu, 1978, 1988). Ogbu (1988, pp. 160-161) describes how involuntary minorities, such as African-Americans, "developed survival strategies to cope with economic, political, and social exploitation...The survival strategies...appear to be in competition with schooling." He observes that "in the minorities'cultural frame of reference, school rules, standard practices, and even academic success are defined as 'white' or 'acting white'," and are, therefore, not socially acceptable.

Ogbu emphasizes that major efforts are needed to create more trusting relationships between blacks and whites to reduce the cultural gap between schools and black children and to convince blacks that the social and economic opportunity structure really is open to them, that there, in fact, will be jobs for them comparable to those that whites obtain with the same levels of education. Other recommendations Ogbu (1988, pp. 163-165) makes include efforts to teach nonimmigrant minority students "how to go to school" and to teach them to adopt a cultural model of schooling similar to that which "works" for immigrants, that is, "accommodation without assimilation."

The programs todáy that have great potential for meeting the steep demands (both inside and outside schools) for successful education for ghetto youth, particularly black youth, seem to be the ones advocated by James Comer $(1980,1987,1988)$ and Henry Levin (1987, 1988a, 1988b). Both Comer's and Levin's programs address contemporary concern for mechanisms to build cuitural and social capital (Coleman \& Hoffer, 1987). Coleman $(1987,1988)$ elaborated on social capital as it applies to the formation of human capital. Coleman's interest is in the ways that social relationships and associations provide structural support for both students as learners and teachers as educators.

Coleman (1988, p. S1 18) foresees the danger of a "declining quantity of human capital embodied in each successive generation." To counteract this possibility, Coleman suggests "the substitution of some kind of formal organization for the voluntary and spontaneous social organization that has in the past been the major source of social capital available to the young." This would appear to be a function served by both Comer's and Levin's approaches.

The belief that "[T] he failure to bridge the social and cultural gap between home and school may lie at the root of the poor academic performance of many of these children" (Comer, 1988, p. 43) has shaped Comer's efforts in the widely publicized intervention project involving the New Haven, Connecticut, School District and the Yale University Child Study Center. In 1969, when the project began with two low income elementary schools, their fourth grade students ranked 32nd and 33rd in achievement among their counterparts in the city's schools. "In 1986, the original project school-with no change in its socioeconomic makeup-tied for third in achievement out of 26 elementary schools, and students ranked about a year above grade level by the fourth grade on the Iowa Test of Basic Skills" (Comer, 1987, p. 16). 
Comer's (1988, p. 46) analysis of the two project schools suggests that "the key to academic achievement is to promote psychological development in students which encourages bonding to the school. Doing so requires fostering positive interactions between parents and school staff, a task for which most staff people are not trained." To accomplish cooperation, a team was formed to "govern and manage" the school. This team included the principal, a mental health professional, representatives from the nonprofessional staff, and elected representatives from parents and teachers. Guidelines were established to mediate between the needs of the principal for authority and those of the team to represent concerns and needs of the students as well as their respective constituencies. In order to assure cooperation, consensus decisionmaking was required. In addition to policy development, parents are also encouraged to participate in the life of the school and to assist in the growth of bonds between the community and school. Comer's (1988, p. 48) efforts also include a social skills curriculum to redress "the problem of social misalignment."

The totality of this program is intended to develop the child socially as well as academically. While the social skills curriculum moves to align economically disadvantaged and minority students with mainstream society, the team approach to school management and governance represents an effort to modify school-community relationships. By involving parents and the community in the formation of social capital, the program also serves to alleviate some of the cultural discontinuity emphasized by Ogbu (1988).

In January 1990, the Rockefeller Foundation awarded a \$15 million grant to promote the use of Comer's program, which was developed in the New Haven public schools and has been adopted by more than 70 schools in nine school districts across the country. The grant will support its implementation in the District of Columbia public schools, the development of a videotape and manual to facilitate dissemination of the program, its use in five other cities in special programs of the National Urban League, and its incorporation into the curriculum of education schools at three universities (Daniels, 1990). In September 1991, the New Jersey education department announced plans to utilize Comer's models in urban schools throughout the state.

Levin's $(1987,1988 \mathrm{a}, 1988 \mathrm{~b})$ accelerated school program represents another effort to achieve both academic and social success by combining effective pedagogical techniques with efforts to build social capital and reduce cultural discontinuity. Levin is trying to build on the strengths of culturally different children, rather than focusing on their deficits (Levin, 1988b, pp. 23-24). Thus, Levin's emphasis on the strengths and abilities of disadvantaged students contradicts conventional wisdom which assumes a need for slower, remedial treatment of such students. According to Levin, "The accelerated school is a transitional elementary school designed to bring disadvantaged students up to grade level by the end of sixth grade so they [can] take advantage of mainstream secondary school instruction." This approach requires an assessment of each child's performance at school entry and sets a series of objectives.

Parents are deeply involved through "a written agreement that clarifies the obligations of parents, school staff, and students," and by "opportunities for parents to interact with the school program and actively assist their children." The program also involves an extended day during which college students and senior citizen volunteers work with individual students (Levin, 1987, pp. 20-21). 
Consistent with Levin's and Comer's approaches, Bryk and his associates (Bryk \& Driscoll, 1988; Bryk, Lee, \& Smith, 1989) conclude that it is not the privatization of schooling which offers the greatest hope for improving education but the degree to which schools function as communities which value student learning in an atmosphere of trust and caring.

We need careful evaluations and longitudinal studies of schools utilizing the Comer and Levin models for educating the disadvantaged. We need more knowledge about how to help poor and educationally disadvantaged parents who are able and willing to help their children be good students.

Furthermore, we need to move beyond the old model of school administration as a separate entity to a model that facilitates the coordination of services for at-risk children. Speaking of the "fragmentation and dysfunctions evident in existing service delivery systems for disadvantaged children," Kirst and Gifford (1988, pp. 21-22) call for moving beyond a "shopping mall" of social agencies on school grounds to "a mechanism [to] coordinate the diagnosis and treatment of children's social pathologies on a case-by-case basis that follows the progress of the child for many years. [This would require] a paradigm shift to children's policy that transcends the individual delivery systems such as schools or health agencies" (pp. 26-27).

At-risk students need programs to address alcoholism, drug addiction, incest, physical and sexual abuse, teenage pregnancy, and broken or nonexistent family relationships. In earlier eras, the family and/or religious institutions often could be counted on to focus on these issues but, in the present societal environment, it is too often the school situation that is the last best hope for salvaging otherwise condemned lives.

Policies based on relinking do not require the financial or political requisites of other proposals. Their potential to have a major impact on the effectiveness of urban education appears great but is not yet established.

\section{IMPLICATIONS}

Although there is consensus among observers on the need to improve urban education, there is no agreement on priority solutions that will have a meaningful impact. No single alternative can be viewed as a panacea. Generally, it seems like the most promising programs and policies are the ones that have not been tried yet. Market solutions to the nation's educational dilemmas are the last example. Clearly, there is no magic bullet and no single variable or single solution in this field. An array of alternatives needs to be implemented and evaluated. Below we specify three policy directions after indicating a number of criteria that successful policy alternatives must meet.

\section{Comprehensiveness}

It is clear that improving urban education will require more than improving urban schools. Urban education is affected by the nation's immigration, economic, social welfare, health, and housing policies. Since these, in general, are not helping urban areas, problems are greater than educational policies can solve. Dealing with the problems of urban education requires treating US cities as resources, not with benign neglect 
(Hodgkinson, 1991). There are many indications that problems, from crack babies to cracks in schools, will get worse if we continue to ignore our urban problems. Nor is the problem primarily one for black children because the new wave of immigration is felt in our urban schools and all children, including Hispanic, Asian, and white, are increasingly at risk.

As one often neglected example, the effects of mass immigration on the nation's urban school systems have never been included in the policymaking process that has supported the expansion of immigration. Immigration policy is solely a discretionary activity of the federal government, but the impact of these political decisions is felt in the local communities where the immigrants reside. It behooves the federal government, therefore, to provide the additional resources needed to meet the emerging requirements that federal policy has fostered. Unless greater federal support is forthcoming for immigrant students already here, either the special needs of many immigrant students will go unmet or there will be a reallocation of programmatic activities that may adversely affect the additional needs of native born students, especially those from minority groups.

\section{Commitment}

In the field of education in this decade, rhetoric has far exceeded commitment. As Boyd (1990) has concluded, "The great danger is that although the political incentives are favorable for proclaiming dramatic programs of reform, the costs of making good on them are generally higher than politicians [and society] are prepared to pay." There is no evidence that marginal changes or low cost efforts are adequate to the scope of the problem, which is one approaching national survival. Even popular and effective programs such as Head Start and Chapter I have not provided even near full coverage. Significant improvement in urban education can only occur if urban education is a national priority, if children become viewed as an important national resource, and if a multibillion dollar increase in expenditures for urban education occurs.

Money is a necessary but not sufficient resource needed for improving the plight of urban school children. Levin (1989) estimates that the cost for helping at-risk youth is about $\$ 21$ billion per year beyond current expenditures. (He assumes an extra $\$ 2,000$ per student is needed for an estimated one-third of the 40 million public school students in the nation.) This would add about $10 \%$ a year to current spending on elementary and secondary education. Jule Sugarman, secretary of the Washington State Department of Social and Health Services, has called for a $\$ 20$ billion Children's Trust (Lewis, 1988). Others have called for doubling or tripling the federal education budget (Lewis, 1988, 1990). Former Congressman Augustus Hawkins, Chairman of the House Labor and Education Committee, proposed doubling the education budget as well as passing the Fair Chance Act, which would require states to equalize funding within their borders (Lewis, 1990).

How financially feasible are such recommendations? This depends on the comparative base one uses to discuss this question. Compared to the potential return on the investment, to the decrease in defense expenditures projected for the next decade, or to the percentage of GNP that other nations spend, large increases in education expenditures targeted to urban education are reasonable. 
This question recently became an object of contention on the institutional battlefield. The Economic Policy Institute (Rasell \& Mishel, 1990) has argued that the United States trailed 13 other industrial countries in its education expenditure. The Herman Kahn Center (Perelman, 1990) responded by arguing that the percentage of gross domestic product is an inappropriate measure to gauge educational commitment and that absolute expenditures per student, which puts the United States second behind Switzerland, is the more appropriate measure. Perelman $(1990$, p. 10) goes on to argue that we are not getting our money's worth anyway and "the attempt to solve education's productivity problem by buying even more of the same academic education is like trying to cure alcoholism by subsidizing the price of bourbon."

The nation needs strong, highly visible and persuasive national leadership, from the White House as well as other national leaders, to start a movement for a "more effective society," one able to compete in the international economy. This would seem to be necessary to enable our schools to become effective enough to achieve the high goals we now are setting for educational improvement in the United States. Are we really serious about the national performance goals President Bush and the state governors have been discussing? These goals, highlighted in the President's State of the Union address, include drastically reducing the dropout rate, increasing the high school graduation rate to $90 \%$, and moving from the bottom on international math and science tests to number 1 by the year 2000 . If we really want to attain these goals, we will need not only much more substantial investments in education and social services, but virtually a new social movement to galvanize public and private energies and to dramatically restructure national priorities. We are far from making the public commitment that is needed. For instance, President Bush has been criticized for ignoring the link between poverty and school failure. As Marc Tucker, president of the National Center for Education and the Economy, remarked, "The math and science goal is critical, but reaching it with $20 \%$ of our kids living in poverty is ludicrous" (Chira, 1990, p. A19).

\section{Universal and Targeted}

Complicating the search for solutions to urban educational problems is the concern that while the concentration of children in central cities with educational problems is a major problem, it is not clear that addressing this problem head-on is politically wise or acceptable. Thus, the Carnegie Foundation's call for a National Urban Schools Program and Jeanie Oakes' suggestions to "Put Urban Schools High on the Public Agenda" are necessary but politically questionable (Carnegie Foundation for the Advancement of Teaching, 1988; Oakes, 1987).

Focusing on the needs of children would be more politically positive than focusing on urban needs. For example, advocating more aid to children, with concentration on "at-risk" children, should be the correct rallying cry of reformers.

The National Rural Institute (Education Week, 1990) recently published a study indicating that rural children are more likely to be at risk than urban children. Similarly, a recent Education Week headline reported "Rural America is Quietly 'Hurting,' Educators Warn" (Weisman, 1990). Thus there is a danger that a focus on children in general may lead to a loss of focus on urban children. 
This is consistent with the call of Weir, Orloff, and Skocpol (1988) and Skocpol (1991) for universal programs which (1) maximize the range of potential recipients, thus avoiding overidentification with the poor or racial minorities, and (2) build a broad, politically powerful, clientele. Stressing the need for investments in children in general and underlining our nation's dependence on all children to maintain economic competitiveness are similar positive political strategies with major implications for urban students.

\section{Value-based}

Even if favorable state court decisions and a large increase in federal aid to urban areas occurred, urban educational problems would not be quickly solved. We also have a crisis in values and in educational institutions. The consistent finding that family background is strongly related to academic achievement and the decline in SAT scores over time suggest that our society does not value academic success the way it should or might. As we noted above, time spent by youth on television and, to some extent, part-time jobs should be reallocated to education. The nation needs a change in values similar to the change that led to a decrease in the percentage of the population smoking tobacco from $55 \%$ in 1964 to $26 \%$ today (Koop, 1990). Eisenberger's $(1990$, p. 32) research on the decline of the work ethic in the United States has led him to conclude that "The traditional components of the work ethic - the moral value of industriousness, the willingness to work hard for material gain, and the pride of accomplishment in carrying out one's job with skill and care-could be fostered in courses on history, civics, and contemporary national affairs."

\section{Community-based}

It is clear that truly effective educational programs for the disadvantaged must successfully address all three clusters of problems that Ogbu (1988) defined: institutional deficiencies, developmental problems, and cultural discontinuities. To clear all three hurdles is a formidable challenge, but programs such as Comer's New Haven intervention suggest that it can be done. A major impediment, however, is the need to assemble a communitywide combination of broad-based commitment and human resources sufficient to overcome institutional incentive problems and developmental and cultural obstacles. This requires extraordinary leadership and supportive resources from the whole community and society. As a recent RAND study concludes, "A failing urban school system can be turned around only if the entire community unites on its behalf" (Hill, Wise, \& Shapiro, 1989, p. v). Although progress can be made "one school at a time," the kind of programs likely to make a real difference, such as those advocated by Comer and Levin, require not only system-level support from the school district but substantial commitments from the broader community and society.

\section{Research-based}

Current data collection efforts do not provide us with the information we require to judge how students in individual cities or metropolitan areas are achieving on the range of dimensions necessary in today's society. The decentralization of US education 
has made it difficult, politically and operationally, to provide the information required. We need assessments that measure basic and more complex skills in a range of subject areas across appropriate governing units. "By carrying out nationwide tests or paying for them, the federal government could give lower levels of government the information they need to hold schools accountable for their performance" (Chubb \& Hanushek, 1990, p. 245). We need to monitor our urban school districts utilizing a variety of other indicators such as dropout rates, college attendance of high school graduates, and job placements. In addition, demonstration projects and experiments with comprehensive programs, market alternatives, and site-based management with a strong client orientation need to be carefully researched to determine their effectiveness.

\section{Policy Directions}

The description of the problems in urban education today, the policies and programs advocated, and the criteria for success implied by these alternatives, lead us to recommend three macropolicy directions.

First and foremost, the nation needs to direct resources at the problem. Everyone is seeking an inexpensive way out of these dilemmas, even the editors of this volume who reminded the authors of the limits on the federal budget in reaching policy conclusions. We see no inexpensive way to change the fact that millions of urban school children do not come to school ready to learn and that programs that work do not reach all children who would benefit.

The National Commission on Children (1991), chaired by Senator John D. Rockefeller IV from West Virginia, has recommended a credible set of policy alternatives to help children reach school with a reasonable chance of success. In its report, the Commission calls for a $\$ 1,000$ per year refundable tax credit for all children through age 18 , a universal system of health insurance coverage for pregnant women and children through age 18 , and the availability of Head Start for every income-eligible child in the nation. This set of alternatives would greatly help urban children within the universalistic criterion noted above. The Commission also specified eight alternative packages to fund its recommendations including increasing the top marginal tax rate for those joint filers with incomes over $\$ 300,000$ a year and imposing a value-added tax.

Other programs that have been shown to work must be extended to cover all atrisk students in urban areas. While Head Start is included in Rockefeller's commission recommendations, Chapter 1 is not. As we have argued in our section on reaffirmation, this program should be extended.

State courts have been increasingly making decisions based on the notion that a child's economic status should not affect his or her right to an appropriate public education. The federal and state governments should support this principle to the greatest degree possible. This involves not only a continuing effort to concentrate on the reallocation of resources in programs, but also new efforts to help urban school districts equalize resources, taking into account municipal burden and the expense of educating students with special problems. Educational funds must be reallocated to low-wealth districts and at-risk students. The federal government must do a better job of redistributing resources, including helping cities cope with the large number of immigrants in their schools. This could be done through encouraging states to do this and/or direct aid 
to city districts or districts with at-risk students in high cost areas. Other contributors to this volume suggest metropolitan tax base sharing as a reasonable alternative; Wolman and colleagues, for example, argue for federal aid based in part on equity in state funding.

It is clear that money alone will not solve the problems of urban education. Thus our second macropolicy recommendation is to direct research and information, as well as resources, to the problems of urban education. First and foremost, the federal government must ensure that the public knows the extent to which urban students are capable of entering the mainstream of society. How well can they read, calculate, and think? This information must be available on a district and school basis. The information must have meaning within a national and international context. While we worry about invidious comparisons, we are even more dismayed that the extent of problems and the success of potential solutions are not apparent if reasonable school outcome measures are unavailable. Many recent efforts to develop such measures (Pipho, 1991), including those of NAEP, the National Center on Education and the Economy, and the University of Pittsburgh's Learning Research and Development Center, move in the appropriate direction and should be supported.

Hanushek (1986) has argued that since there is no consistent evidence that particular expenditures lead to increased student achievement, just providing schools with more resources would be unwise. While Walberg (1984) has made a convincing argument that some programs and alternatives do consistently raise student achievement, it is clear that we have a lot more to learn about structuring urban schools and systems to utilize methods that motivate and teach urban students.

We conclude that we must take an experimental approach (Campbell, 1969) to urban education reform. We must evaluate different programs with different assumptions while holding to national standards and goals. While we could argue with many of the specifics of the America 2000 strategy, we agree with the premise of the approach: We must create systematic and well-grounded experiments which move beyond the traditional organization and governance of urban public schools.

The potential of alternatives that fundamentally change the relation of the school to its environment, discussed above in terms of restructuring and relinking (e.g., choice, apprenticeship programs, comprehensive delivery programs), hold the most promise for positive change. These are the alternatives that experiments should test first.

The Council of Great City Schools (1991) has taken the initiative in developing legislation under the rubric of the Urban America Schools Act, which includes provisions for:

- $\$ 1.5$ billion a year through 2000 in formula grants to 84 eligible inner city public school systems and community-based groups to move the schools toward the nation's urban education goals;

- $\$ 1.5$ billion a year through 2000 in formula grants to renovate and repair aging inner city school buildings;

- $\$ 100$ million for research and evaluation of progress urban schools are making toward the goals;

- Incentive grants to inner city schools that make unusual progress toward meeting the USA goals (p. 10-11). 
This is the basis of what could serve as a focus for renewing urban education. However, we need to move beyond resources and research to more fundamentally alter urban education.

It is a cliché that schools reflect society, but it is a true cliché. We believe that the problem in urban education are so fundamental that resources and research will not be enough. We also need to direct rhetoric toward the problem with the goal of changing our society's values. Our nation must reexamine its values vis-à-vis children and education and the President, perhaps by default, must lead this reexamination. As a nation, we simply are not putting the effort required into our children and our schools. There are many indications of this, from the low percentage of our GNP invested in education, through the many children born without the benefit of two parents, through the attention devoted to cars and television among our children. This is a national problem that will take national leadership but can only be changed by responsibility shared across state governments, the private sector, etc. Our nation is not investing enough in our children, but we also believe that children are not investing enough in themselves.

\section{CONCLUSION}

Although there is agreement on the grim realities of urban education today and the likely problems to be faced in the future, no consensus on solving the problems of urban education exists. While some rays of light are visible, they do not converge. We have defined the parameters of a solution set and a number of policies that will help address the urban education crisis, but the political will and capabilities to build a solution now seem a long way off. We need to recognize that our nation must improve the education of all children for the economic and political health of the nation. Where the nation will get the political and economic will and ability to accomplish this task is not now apparent.

ACKNOWLEDGMENTS: The authors are indebted to J. Barry Cullingworth who read an early draft of this paper and offered helpful suggestions. They thank him, Sue Smock (NASULGC liaison), and the anonymous reviewers, all of whom improved the quality of this paper.

\section{REFERENCES}

Abbott v. Burke. 575 A. 2d 359 (N.J. 1990).

Baker, K., \& de Kantor, A. (1981). Effectiveness of bilingual education: a review of the literature. Washington, D.C.: U.S. Department of Education.

Bates, P. (1990). Desegregation: can we get there from here? Phi Delta Kappan, 72(1), 8-17.

Berryman, S. E. (1987). Shadows in the wings: the next educational reform. Paper presented at the Educational Policy Forum, Washington, D.C., March 13.

Bishop, J. (1989). Why the apathy in American high school? Educational Researcher, 18(1), 610.

Bogen, E. (1987). Immigration in New York. New York: Praeger Publishers.

Boyd, W. L. (1990). What makes ghetto schools work or not work? Paper presented at the conference on the Truly Disadvantaged, Northwestern University, October 19-21. 
Briggs, V. M., Jr. (1984). Immigration policy and the American labor force (Chaps. 2 \& 3). Baltimore: Johns Hopkins University Press.

Bryk, A. S., \& Driscoll, M. E. (1988). The high school as community: contextual influences and consequences for students and teachers. Paper prepared for the National Center on Effective Secondary Schools, University of Wisconsin, November.

Bryk, A. S., Lee, V. E., \& Smith, J. B. (1989). High school organization and its effects on teachers and students: an interpretative summary of research. Paper presented at the Invitational Conference on Choice and Control in American Education at the Robert M. La Follette Institute of Public Affairs, University of Wisconsin-Madison, May 18.

Campbell, D. T. (1969). Reforms as experiments. American Psychologist, 24, 409-429.

Carnegie Foundation for the Advancement of Teaching. (1988). An imperiled generation: saving urban schools. Princeton: Princeton University Press.

Carnegie Task Force on Teaching as a Profession. (1986). A nation prepared: teachers for the 21st century. New York: Carnegie Forum on Education and the Economy.

Carsrud, K., \& Curtis, J. (1980). Evaluation of achievement outcomes: Austin's experience. Paper presented at the National Conference on Longitudinal Evaluation of Bilingual Programs, Austin, TX.

Chira, S. (1990, February 2). Schools plan: big goals, little money. New York Times, p. A19.

Chubb, J. E., \& Hanushek, E. A. (1990). Reforming education reform. In H. J. Aaron (Ed.), Setting national priorities: policy for the nineties. Washington, D.C. Brookings Institution.

Chubb, J., \& Moe, T. (1988). Politics, markets, and the organization of school. American Political Science Review, 82, 1065-1087.

Chubb, J. E., \& Moe, T. M. (1990). Politics, markets, and America's schools. Washington, D.C.: Brookings Institution.

Clark, D. L., \& Astuto, T. A. (1990). The disjunction of federal educational policy and educational needs in the 1990s. In D. E. Mitchell \& M. E. Goertz (Eds.), Education politics for the new century, pp. 11-25. London: Falmer Press.

Coleman, J. S. (1987). Families and schools. Educational Researcher, 16(6), 32-38.

Coleman, J. S. (1988). Social capital in the creation of human capital. American Journal of Sociology, 94(Supp.), S95-S120.

Coleman, J. S., \& Hoffer, T. (1987). Public and private high schools: the impact of communities. New York: Basic Books.

Comer, J. P. (1980). School power: implications of an intervention project. New York: Free Press.

Comer, J. P. (1987). New Haven's school-community connection.Educational Leadership, 44(6), 13-16.

Comer, J. P. (1988). Educating poor minority children. Scientific American, 259(5), 42-48.

Council of Great City Schools. (1986). The condition of education in the great city schools: a statistical profile. Washington, D.C.: Author.

Council of Great City Schools. (1987). Challenges to urban education: results in the making. Washington, D.C.: Author.

Council of Great City Schools. (1988). Teaching and leading in the great city schools. Washington, D.C.: Author.

Council of Great City Schools. (1991). Strategies for success: a plan for achieving the national urban education goals. Washington, D.C.: Author.

Daniels, L. A. (1990). Fifteen million to aid partnership of teachers, parents and pupils. New York Times, January 24, p. B6.

Edmonds, R. (1979a). Effective schools for the urban poor. Educational Leadership, 37(1), 1524.

Edmonds, R. (1979b). Some schools work and more can. Social Policy, 9(2), 28-32.

Education Week. (1990, June 6). Research. 9(37), 9. 
Eisenberger, R. (1990, Summer). Try harder, America. University of Delaware Magazine. 2(4), 32.

Eubanks, E. (1990). Learning approaches for urban students: school cultures that support them. Paper prepared for the NASULGC Committee on Urban Education.

Fiske, E. (1988, June 23). Racial shifts challenge U.S. schools. New York Times, p. A-16.

Hamilton, S. F. (1987). Apprenticeship as a transition to adulthood in West Germany. American Journal of Education, 95(2), 314-345.

Hanushek, E. A. (1986). The economics of schooling: production and efficiency in public schools. Journal of Economic Literature. 24: 1141-1177.

Hill, P. T., Wise, A. E., \& Shapiro, L. (1989). Educational progress: cities mobilize to improve their schools. Santa Monica, CA: RAND Corporation.

Hodgkinson, H. (1991). Reform versus reality. Phi Delta Kappan, 73(1), 9-16.

Jaynes, G. D., \& Williams, R. M., Jr. (1989). The schooling of black Americans. In G. D. Jaynes \& R. M. Williams, Jr. (Eds.), A common destiny: blacks and American society, pp. 331389. Washington, D.C.: National Academy Press.

Johnston, P., Allington, R., \& Afflerbach, P. (1985). The congruence of classroom and remedial instruction. Elementary School Journal, 102, 173-175.

Kennedy, M., Birman, B., \& Demaline, R. (1986). The effectiveness of Chapter 1 services. Second interim report from the National Assessment of Chapter 1, Office of Educational Research and Improvement, U.S. Department of Education. Washington, D.C.: U.S. Government Printing Office.

Kirst, M. W., \& Gifford, B. (1988). Politics of government efforts to improve the disadvantaged. Paper presented at Stanford Centennial Conference on Accelerating Education for Disadvantaged Children, Stanford, University, November.

Knapp, M. S., \& Shields, P. M. (1990). Reconceiving academic instruction for the children of poverty. Phi Delta Kappan, 71, 752-758.

Koop, C. E. (1990). [Speech to the DuPont Company, Wilmington, DE, September 26].

La Morte, M. W. (1989). Courts continue to address the wealth disparity issue. Educational Evaluation and Policy Analysis, 11(1), 3-15.

Levin, H. M. (1986). Costs and cost-effectiveness of computer-assisted instruction. In J. A. Culbertson \& L. Cunningham, Microcomputers in education, pp. 156-174. Chicago: University of Chicago Press.

Levin, H. M. (1987). Accelerated schools for disadvantaged students. Educational Leadership, 44(6), 19-21.

Levin, H. M. (1988a). Accelerated schools for at-risk students. New Brunswick, NJ: Rutgers University, Center for Policy Research in Education.

Levin, H. M. (1988b). Accelerating elementary education for disadvantaged students. In School success for students at risk: analysis and recommendations of the Council of Chief State Officers, pp. 209-226. Orlando, FL: Harcourt-Brace-Janovich.

Levin, H. M. (1989). Financing the education of at-risk students. Educational Evaluation and Policy Analysis, $11(1), 47-60$.

Levine, D., \& Lezotte, L. (1990). Unusually effective schools. Madison, WI: National Center for Effective Schools Research and Development.

Leviton, L. C., \& Boruch, R. F. (1984). Why the compensatory education evaluation was useful. Journal of Policy Analysis and Management, 3, 299-305.

Lewis, A. C. (1988). Washington report: promises, promises. Phi Delta Kappan, 70, 100.

Lewis, A. C. (1990). Washington commentary: money talks. Phi Delta Kappan, 71, 500-501.

Llanes, J. (1981). The sociology of bilingual education in the U.S. Journal of Education. 163, 72-84. 
McConnell, B. (1980). Effectiveness of individualized bilingual instruction for migrant students. Ph.D. dissertation. Washington State University.

McGuire, K. (1990). Business involvement in the 1990s. In D. Mitchell \& M. Goertz (Eds.), Education politics for the new century, pp. 107-117. London: Falmer Press.

Meier, D. (1989, May 31). Helping youth shun "ideals" of violence. Education Week, p. 32.

Michaelsen, J. B. (1977). Revision, bureaucracy, and school reform. School Review, 85, 299246.

Michaelsen, J. B. (1981). A theory of decision making in the public schools: a public choice approach. In S. B. Bacharach (Ed.), Organizational behavior in schools and school districts. New York: Praeger.

National Advisory Commission on Civil Disorders. (1968). Report of the national commission on civil disorders. New York: New York Times Company.

National Center for Educational Statistics. (1990). The condition of education. Vol. 1. Elementary and Secondary Education, L. T. Ogle (Ed.). Washington, D.C.: U.S. Department of Education, Office of Educational Research and Improvement. U.S. Government Printing Office.

National Commission on Children. (1991). Beyond rhetoric: a new American agenda for children and families. Washington, D.C.: Author.

National Education Association. (1990). Federal education funding: the cost of excellence. Washington, D.C.: Author.

National School Boards Association. (1988). A survey of public education in the nation's urban school districts. Alexandria, VA: Author.

Oakes, J. (1987). Improving inner-city schools: current directions in urban district reform. Santa Monica, CA: RAND Corporation.

Ogbu, J. U. (1978). Minority education and caste: the American system in cross-cultural perspective. New York: Academic Press.

Ogbu, J. U. (1988). Diversity and equity in public education. Community forces and minority school adjustment and performance. In R. Haskins \& D. MacRae (Eds.), Policies for America's public schools: teachers, equity, and indicators. Norwood, NJ: Ablex Publishing.

Oxford Analytica. (1986). America in perspective. Boston: Houghton Mifflin.

Pallas, A. M., Natriello, G., \& McDill, E. L. (1989). The changing nature of the disadvantaged population: current dimensions and future challenges. Educational Researcher, 18(5), 1622.

Perelman, L. J. (1990). The "acanemia" deception. Hudson Institute Briefing Paper. Indianapolis, IN: Herman Kahn Center.

Personick. V. (1987). Industry output and employment through the end of the century. Monthly Labor Review, 110, 30-45.

Piccigallo, P. R. (1989). Renovating urban schools is fundamental to improving them. Phi Delta Kappan, 70, 402-406.

Pipho, C. (1991). Stateline: the unbridled, undebated national test. Phi Delta Kappan, 72, 574575.

Rasell, E., \& Mishel. L. (1990). Shortchanging education: the cost of excellence. Washington, D.C.: Economic Policy Institute.

Reed, S., Craig, R., \& Sautter, R. C. (1990). Children of poverty: the status of 12 million young Americans. Phi Delta Kappan, 7l(10), K1-12.

Rosenholtz, S. J. (1985). Effective schools: interpreting the evidence. American Journal of Education, 93, 352-388.

Rossell, C. H. (1990). The carrot or the stick for school desegregation policy: magnet schools or forced busing. Philadelphia: Temple University Press. 
Rossell, C. H., \& Hawley, W. D. (Eds.). (1983). The consequences of school desegregation. Philadelphia: Temple University Press.

San Antonio Independent School District v. Rodriguez, 411 U.S. 1 (1973).

Schorr, L. B. (1988). Within our reach: breaking the cycle of disadvantage. New York: Doubleday.

Schweinhart, L. J., \& Weikart, D. P. (1980). Young children grow up: the effects of the Perry preschool program on youths through age 15. Ypsilanti, MI: High/Scope.

Shanker, A. (1990). The end of the traditonal model of schooling-and a proposal for using incentives to restructure our public schools. Phi Delta Kappan, 71, 345-357.

Skocpol, T. (1991). Targeting within universalism: politically viable policies to combat poverty in the United States. In C. Jencks \& P. E. Peterson (Eds.), The urban underclass. Washington, D.C.: Brookings Institution.

Sykes, G., \& Elmore, R. F. (1989). Making schools manageable. In J. Hannaway \& R. Crowson (Eds.), The politics of reforming school administration. New York: Falmer Press.

Tauber, K. (1990). Desegregation of public school districts: persistence and change. Phi Delta Kappan, 72, 18-24.

U.S. Congress. (1988, December 4). The educational deficit. Report of the Subcommittee on Education and Health of the Joint Economic Committee (p. 18).

U.S. National Commission on Excellence in Education. (1984). A nation at risk: the full account. Cambridge, MA: USA Research.

Verstegen, D. A., \& Clark, D. L. (1988). The diminution in federal expenditures for education during the Reagan administration. Phi Delta Kappan, 70, 134-138.

Wallberg, H. (1984). Improving the productivity of America's schools. Educational Leadership, $47(8), 19-27$.

Waste, R. J. (1989). Federal urban policy in the 1990s: deja vu and disaster. Urban Resources, $5(2), 21-24$.

Weir, M., Orloff, A. S., \& Skocpol, T. (1988). Epilogue: the future of social policy in the United States: political constraints and possibilities. In M. Weir, A. S. Orloff, \& T. Skocpol, (Eds.), The politics of social policy in the United States, pp. 421-445. Princeton: Princeton University Press.

Weisman, J. (1990). Rural American is quietly "hurting," educators warn. Education Week, 10(6), 10.

William T. Grant Foundation Commission on Work, Family, and Citizenship. (1988). The forgotten half: pathways to success for America's youth and young families. Phi Delta Kappan. 70, 281-289.

Wilson, W. J. (1987). The truly disadvantaged: the inner city, the underctass, and public policy. Chicago: University of Chicago Press.

Wise, A. (1990). A response to America's reform agenda: the National Institutes for Educational Improvement. Educational Researcher, 19(4), 22-25. 